\title{
Lipid droplets in cultured luteal cells in non-pregnant sheep fed different planes of nutrition
}

Vilaivan Khanthusaeng ${ }^{\mathrm{b}}$, Jiratti Thammasiri ${ }^{\mathrm{b}}$, Casie S Bass ${ }^{\mathrm{a}}$, Chainarong Navanukraw ${ }^{\mathrm{b}}$, Pawel Borowicz ${ }^{\mathrm{a}}$, Dale A Redmer ${ }^{\mathrm{a}}$ and Anna T Grazul-Bilska ${ }^{\mathrm{a}^{*}}$

${ }^{a}$ Department of Animal Sciences, North Dakota State University, Fargo, ND 58108, USA

${ }^{b}$ Agricultural Biotechnology Research Center for Sustainable Economy (ABRCSE), Department of Animal Science, Faculty of Agriculture, Khon Kaen University, Khon Kaen 40002, Thailand

*Corresponding author: Anna T. Grazul-Bilska, Department of Animal Sciences, North Dakota State University, Fargo, ND 58102, USA. Tel: 701-2317992; fax: 701-231-7590; E-mail address: Anna.Grazul-Bilska@ndsu.edu

Running head: Lipid droplets in ovine luteal cells in vitro

Manuscript received

(C) 2016. This manuscript version is made available under the Elsevier user license http://www.elsevier.com/open-access/userlicense/1.0/ 


\section{A B S T RA C T}

Accumulation of lipid droplets (LD) in luteal cells likely is important for energy storage and steroidogenesis in the highly metabolically active corpus luteum (CL). The objective of this study was to determine the effect of plane of nutrition on progesterone (P4) secretion, and lipid droplet number and size in cultured ovine luteal cells. Ewes were randomly assigned to one of three nutritional groups: control $(C ; 100 \%$ NRC requirements, $n=9)$, overfed $(O ; 2 x C, n=12)$, or underfed $(\mathrm{U} ; 0.6 \mathrm{xC}, \mathrm{n}=10)$. Superovulation was induced by follicle stimulating hormone injections. At the early and mid-luteal phases of the estrous cycle, CL were dissected from ovaries, and luteal cells isolated enzymatically. Luteal cells were incubated overnight in medium containing serum in chamber slides. Media were then changed to serum-free and after $24 \mathrm{~h}$ incubation, media were collected for P4 analysis, and cells were fixed in formalin and stained with BODIPY followed by DAPI staining. Z-stacks of optical sections of large and small luteal cells (LLC and SLC, respectively) were obtained using a laser-scanning microscope. Rendered 3D images of individual LLC and SLC were analyzed for cell volume, and total and individual LD volume, number and percentage of cellular volume occupied by LD by using Imaris software. Concentrations of $\mathrm{P} 4$ in serum and media were greater $(\mathrm{P}<0.05)$ at the mid than earlyluteal phase, and were not affected by nutritional plane. LD total volume and number were greater $(\mathrm{P}<0.001)$ in LLC than SLC; however, mean volume of individual LD was greater $(\mathrm{P}<0.02)$ in SLC than LLC. In LLC, total LD volume was greater $(\mathrm{P}<0.02)$ in $\mathrm{O}$ than $\mathrm{C}$ and $\mathrm{U}$ ewes. In SLC, total LD volume and number was greater $(\mathrm{P}<0.003)$ at the mid than early-luteal phase, and percentage of cell volume occupied by LD was greater $(\mathrm{P}<0.002)$ in $\mathrm{U}$ than $\mathrm{C}$ and $\mathrm{O}$ ewes. These data demonstrate that both stage of luteal development and nutritional plane affect 
selected LD measurements and thus may affect luteal functions. Furthermore, these data confirm that LD dynamics differ among parenchymal steroidogenic luteal cell types.

Keywords: Lipid droplets, BODIPY, Luteal cells, Ovary, Sheep 


\section{Introduction}

Through secretion of progesterone (P4), corpora lutea (CL) control reproductive cyclicity and preparation of the uterus for potential pregnancy in mammalian species (Niswender et al., 1999; Niswender, 2002; Miyamoto et al., 2009; Shirasuna et al., 2012; Stouffer et al., 2013). The CL consists of several cell types including parenchymal steroidogenic large and small luteal cells (LLC and SLC, respectively), and non-parenchymal cells including endothelial cells, pericytes, fibroblast, blood cells and others (Milvae et al., 1996 ; Vonnahme et al., 2006; Devoto et al., 2009). Parenchymal LLC and SLC have been well characterized for several species demonstrating different steroidogenic activity, responsiveness to luteinizing hormone (LH), morphology and other features in ruminants and other species (O'Shea et al., 1986, 1989; Niswender and Nett, 1994;). Furthermore, it has been shown that luteal cells contain large numbers of lipid droplets (LD; O'Shea et al., 1986, 1989, 1990; Fields et al., 1992; Fields and Fields, 1996; Towns et al., 1999); but the function of LDs in luteal cells has not been investigated in detail. Moreover, several studies demonstrated that selected functions of CL, including P4 secretion, can be affected by nutritional plane (O'Callaghan and Boland, 1999; Kaminski et al., 2015). However, the effects of diet on LDs in the CL have not been investigated for any species.

Lipid droplets are cellular organelles serving as an energy reservoir as well as mediators in physiological and pathological conditions (Farese and Walther, 2009; Murphy et al., 2009; Beller et al., 2010; Digel et al., 2010; Greenberg and Coleman, 2011; Greenberg et al., 2011; Zechner et al., 2012; Konige et al., 2014; Ohsaki et al., 2014; Previs et al., 2014; Wilfling et al., 2014). Lipid droplets contain numerous molecules including fatty acids as reservoirs for energy substrates, and cholesterol esters and cholesterol for membrane biosynthesis and steroid 
production (Beller et al., 2010; Brasaemle and Wolins, 2012). In addition, LDs have an ability to protect cells from lipotoxicity (Farese and Walther, 2009). Associated with LDs are numerous proteins including the family of perilipins (PLIN), cell death-inducing DNA fragmentation factor 45-like effector (CIDE), hormone-sensitive lipase (HSL) and others that play regulatory roles in steroidogenesis and lipid metabolism (Londos et al., 1995; Beller et al., 2010; Zechner et al., 2012; Yang et al., 2012; Konige et al., 2014; Manna et al., 2015). Thus, it has been postulated that LDs are highly dynamic, heterogeneous cellular organelles interacting with other organelles including endoplasmic reticuli, mitochondria and peroxisomes (Murphy et al., 2009; Beller et al., 2010; Digel et al., 2010; Walther and Farese, 2012).

A variety of methodologies have been used to identify LDs in cells and tissues including electron, confocal or light microscopy, histological binding methods (e.g., oil red O, Nile red, BODIPY), and/or immunohistochemistry to detect proteins associated with LDs (e.g., PLIN) in different organs (Straub et al., 2008, 2013; Digel et al., 2010; Ohsaki et al., 2010, 2014; Walther and Farese, 2012; Crunk et al., 2013; Fujimoto et al., 2013; Suzuki et al., 2013; Klymchenko and Kreder, 2014). Application of image analysis allows for quantitative evaluation of LDs in a cell or tissue (Straub et al., 2008; Prats et al., 2013). In this study, we generated confocal 3D images of cultured luteal cells stained using BODIPY followed by image analysis to determine several measurements of a cell and corresponding LDs.

Although luteal functions have been studied intensively, very little is known about importance of LDs in the CL for any species. We hypothesized that selected measurements of LDs will differ in LLC and SLC, and will be affected by the stage of the estrous cycle and plane of nutrition. The objectives of this study were to optimize and validate novel method of LD expression in cultured luteal cells, and determine the total and individual volume and number of 
LDs in cultured LLC and SLC from the early and mid-luteal phases of the estrous cycle from ewes fed control, excess and restricted diets.

\section{Materials and Methods}

\section{Animal and Experimental Design}

All animal procedures were approved by the North Dakota State University (NDSU) Institutional Animal Care and Use Committee (\#A12013). The study was initiated during the normal breeding season in August and finished in December.

Non-pregnant, non-lactating Rambouillet ewes between 3-5 years of age and of similar genetic background were individually penned at the Animal Nutrition and Physiology Center on the NDSU campus. Ewes were stratified by weight and randomly assigned into one of three dietary treatments: control $(C ; n=9)$ received a maintenance diet (100\% NRC requirements; 2.4 Mcal of metabolizable energy [ME]/kg diet dry matter), overfed $(\mathrm{O} ; \mathrm{n}=12)$ received $200 \%$ NRC requirements, and underfed $(\mathrm{U} ; \mathrm{n}=10)$ received $60 \%$ NRC requirements 60 days prior to the onset of the estrous cycle (day 0). Diet composition is provided in the Table 1. Ewes were fed half of their individual diet daily at 0800 and the remaining half at 1500 , and all portions were consumed. For the duration of the experiment, ewes were weighed and body condition score (BCS) was determined weekly (Kaminski et al., 2015). Diets were adjusted weekly for each ewe to ensure the proper nutritional plane was achieved at day 0 , and maintained throughout the estrous cycle until completion of experiment at the early (day 5) or mid (day 10)-luteal phases of the second estrous cycle. The nutritional treatment has been described in detail before (GrazulBilska et al., 2015; Kaminski et al., 2015). 
Estrus was synchronized by insertion of a controlled internal drug release (CIDR) device for 14 days. Approximately $36 \mathrm{~h}$ after removal of the CIDR ewes were considered in estrus and treated as day 0 of the estrous cycle (Kaminski et al., 2015). Ewes were injected twice daily (morning and evening) with follicle stimulating hormone (FSH-P; Sioux Biochemical, Sioux Center, IA, USA) on days 13, 14 and 15 of the estrous cycle (5, 4 and $3 \mathrm{mg} / \mathrm{injection,}$ respectively; Grazul-Bilska et al., 1991, 2001).

\section{Tissue and Blood Collection}

At the early and mid -luteal phases of the estrous cycle, ovaries were collected, immersed in phosphate buffered saline (PBS) and transported to the laboratory. Then, CL were dissected from ovaries, and minced for enzymatic digestion as previously described (Grazul-Bilska et al., 1991, 2001). Blood samples were also collected at the early and mid-luteal phases, centrifuged (20 min at $1,500 \mathrm{~g}$ ), and serum was stored at $-20^{\circ} \mathrm{C}$ until $\mathrm{P} 4$ analysis.

\section{Dissociation, Culture and Imaging of Luteal Cells}

Minced luteal tissues were incubated in dissociation medium consisting of Hank's Balanced Salt Solution (HBSS; Gibco, Grand Island, NY, USA) supplemented with collagenase type 4 (0.1\% wt/vol; Worthington, Lakewood, NJ, USA), bovine serum albumin (BSA; $2 \%$, wt/vol; Sigma, St. Louis, MO), penicillin/streptomycin (P/S; $100 \mathrm{U} / \mathrm{mL} / 100 \mu \mathrm{g} / \mathrm{mL}$; Gibco) in a shaking (100 cycles/min) water bath at $37 \mathrm{C}$ in a capped 50-mL Erlenmeyer flasks. After initial 15-20 min incubation, medium containing dispersed luteal cells was aspirated, and approximately $3 \mathrm{~mL}$ of fresh dissociation medium was added to the remaining tissue. Dissociation medium was then aspirated and replaced every 7-10 minutes for $\sim 10$ incubations. 
This process was continued for approximately $2-3 \mathrm{~h}$. At the end of collection, medium containing dispersed luteal cells was centrifuged $(600 \mathrm{x} \mathrm{g})$ for $10 \mathrm{~min}$. The pellet was washed three times with HBSS containing P/S (as described above) and then resuspended in the same medium via trituration with a siliconized Pasteur pipette. The cell suspension was filtered through a sterile nylon filter with $50 \mu \mathrm{m}$ pores (Tetko, New York, NY, USA) to remove pieces of tissue and then centrifuged (600 x g; $10 \mathrm{~min})$. Cells were resuspended in Dulbecco's Modified Eagle Medium (DMEM; Gibco) plating medium containing 10\% (vol/vol) calf serum (CS; Gibco), 10\% fetal bovine serum (FBS; Gibco) and P/S. Luteal cells were counted using a hemocytometer and viability was evaluated by trypan blue (Gibco) exclusion. The viability of freshly dispersed luteal cells was $87.1 \pm 2.4 \%$ and the proportion of LLC in the total steroidogenic cell population was $8.3 \pm 1.6 \%$ for early and mid-luteal phases for all nutrition treatments.

Cells were plated in 8-chamber plastic slides (Ibidi GmbH, Martinsried, Germany) at a concentration of 75,000 cells/well//0.5 ml in DMEM medium containing 10\% CS, 10\% FBS and P/S. After overnight incubation, medium was changed to serum-free DMEM and cells were cultured for $24 \mathrm{~h}$. Then, medium was collected for P4 analysis and cells were fixed in 3\% formalin followed by BODIPY 493/503 staining ( $1 \mu \mathrm{g} / \mathrm{ml}$ of PBS; Molecular Probes, Eugene, OR) for 20 min (Ohsaki et al., 2010; Spangenburg et al., 2011). Nuclei were stained using DAPI solution (300 mM; Molecular Probes,). Optical sections including whole LLC or SLC were obtained using a confocal laser-scanning microscope (Zeiss LSM700, Zeiss Inc., Thornwood, NY) using Plan-Apochromat 40X/1.40NA oil immersion lens. For each sheep, images of 6 SLC and 6 LSC were generated. Rendered 3D images (7.5-24 $\mu \mathrm{m}$ thick z-sections, 15-55 z-sections per cell, depends on cell size) were analyzed for cell volume, total and individual LDs volume, and LD's number by using "Cells" module of Imaris software (Bitplane, South Windsor, CT). 
Analysis process consisted of 26 major steps, was standardized according to manufacturer recommendations and applied to each image with the same parameters for cell and LD detection, measurements, and data collection. Generation and analysis of one image took $\sim 3$ min and 3-6 min, respectively.

\section{Progesterone Analysis}

Progesterone concentration in serum and medium was determined using a solid phase chemiluminescence, competitive binding immunoassay (Immulite 1000, Siemens), as previously described (Grazul-Bilska et al., 2014; Kaminski et al., 2015). Each sample was run in duplicate. The intra-assay CV was $10.3 \%$.

\section{Statistical analysis}

Data were analyzed using the general linear model (GLM) procedures of SAS 9.2 (Cary, NC, USA). The model included plane of nutrition, phase of the estrous cycle, cell type and their interactions. Means were separated using the least square means (LSM) option of SAS and were considered significant when $\mathrm{P} \leq 0.05$.

\section{Results}

Initial body weight $(\mathrm{BW})$ and $\mathrm{BCS}$ were similar for all groups $(56.3 \pm 1 \mathrm{~kg}$ and $2.8 \pm 0.05$, respectively). Throughout the duration of the study, $\mathrm{C}$ maintained $\mathrm{BW}$ and $\mathrm{BCS}, \mathrm{O}$ ewes gained $(\mathrm{P}<0.001) 15.8 \pm 1 \mathrm{~kg}$ and BCS increased to $3.2 \pm 1$, and $\mathrm{U}$ ewes lost $(\mathrm{P}<0.001) 11.2 \pm 1 \mathrm{~kg}$ and BCS decreased $(\mathrm{P}<0.0001)$ to $2 \pm 0.1$. After 60 days of nutritional treatment, the desired models of C, $\mathrm{O}$ and $\mathrm{U}$ ewes were achieved, similar to our previous studies (Grazul-Bilska et al., 2012, 
2015; Kaminski et al., 2015). Concentration of P4 in serum and media was greater $(\mathrm{P}<0.05)$ at the mid than early-luteal phase (serum: $14.0 \pm 2.8 \mathrm{ng} / \mathrm{mL}$ vs. $7.0 \pm 1.2 \mathrm{ng} / \mathrm{mL}$; media: $5.5 \pm 0.7$ ng/mL vs. $1.4 \pm 0.3 \mathrm{ng} / \mathrm{mL}$, respectively), and was not affected by nutritional plane.

Lipid droplets were detected in the cytoplasm of all LLC and SLC (Fig. 1A,B). Image analysis software (Imaris) generated a 3D image of each cell (Fig. 1C, D) which was used to determine cell volume (Fig. E, F), the LD number, and total and individual (medium and median volume of a droplet) LD volume (Fig. 1G,H, I, J).

As expected, volume of LLC was greater $(\mathrm{P}<0.0001)$ than SLC (Fig. 2A). Overall, cell volume was greater $(\mathrm{P}=0.004)$ at the mid than early luteal phase of the estrous cycle (Fig. 2A). However, plane of nutrition did not affect cell volume (Fig. 2A). Interactions $(\mathrm{P}<0.003)$ between cell type and luteal phase demonstrated that volume of LLC at the mid-luteal phase was greater than at the early luteal phase.

Total volume of LDs/cell was greater $(\mathrm{P}<0.0001)$ in LLC than SLC, and greater $(\mathrm{P}<0.01)$ at the mid than early luteal phase of the estrous cycle (Fig. 2B). Interactions $(\mathrm{P}=0.02)$ among plane of nutrition, cell type and stage of the estrous cycle demonstrated that LDs volume in LLC was greater in $\mathrm{O}$ group at the mid-luteal phase than in other groups (Fig. 2B).

The number of LDs/cell was greater $(\mathrm{P}<0.0001)$ in LLC than SLC, and it was greater $(\mathrm{P}=0.02)$ at the mid than early luteal phase. Tendency for interactions $(\mathrm{P}=0.1)$ among plane of nutrition, cell type and stage of the estrous cycle demonstrated that LD number/cell was greater in LLC in the O group at the mid-luteal phase than in other groups (Fig. 2C).

The mean volume of individual LDs was greater $(\mathrm{P}=0.02)$ in SLC than LLC, and was not affected by nutritional plane or stage of the estrous cycle. Tendency for interactions $(\mathrm{P}<0.09)$ among plane of nutrition, cell type and stage of the estrous cycle demonstrated that mean volume 
of individual LD was greater in SLC in U group at the mid luteal stage than in other groups with the exception of SLC in C group at the early luteal phase; in addition, the mean volume of individual LD was greater in SLC in C group at the early luteal phase than LLC at the early luteal phase in $\mathrm{O}$ and $\mathrm{U}$ ewes, and LLC at the mid-luteal phase in C and $\mathrm{U}$ groups, and SLC at the early luteal phase in $\mathrm{O}$ group, and mid luteal phase in C group (Fig. 2D).

The median volume of individual LD was greater $(\mathrm{P}=0.02)$ in SLC than LLC, and was not affected by nutritional plane or stage of the estrous cycle. Interactions $(\mathrm{P}=0.01)$ between plane of nutrition and stage of the estrous cycle demonstrated that median volume of individual LD was greater in SLC from the mid luteal phase in U group than in LLC from early-luteal phase in $\mathrm{O}$ and $\mathrm{U}$ groups, from the mid-luteal phase in all nutritional groups, SLC at the early luteal phase in $\mathrm{O}$ and $\mathrm{U}$ groups, and mid luteal phase in $\mathrm{C}$ group (Fig. 2E).

The percentage of cell volume occupied by LD was greater $(\mathrm{P}<0.05)$ at the mid than early luteal phase in LLC and SLC, and tended $(\mathrm{P}=0.09)$ to be greater in $\mathrm{U}$ than $\mathrm{C}$, but was not affected by cell type. Interactions between plane of nutrition and cell type $(\mathrm{P}<0.01)$, and between stage of the estrous cycle and cell type $(\mathrm{P}=0.02)$, demonstrated that percentage of cell volume occupied by LD in SLC from the mid luteal stage in U group were greater than any other group with the exception of LLC at the mid luteal stage from O group (Fig. 2F).

\section{Discussion}

In the present experiment, we used software combined with fluorescent staining and confocal microscopy that allowed for generation of 3D images of cell volume, and cytoplasmic localization of LDs marked with BODIPY, and nuclei marked with DAPI in cultured LLC and SLC from the early and mid-luteal phases of the estrous cycle. Similar and other methodologies 
including 3D linear Raman spectroscopy combined with fluorescent microscopy, confocal microscopy combined with immuno-colocalization of LDs with selected antigens or threedimensional electron microscopy tomography have been used to identify presence, size and/or other features of LDs in mouse liver cells (Crunk et al., 2013; Majzner et al., 2014), human leukocytes (Melo et al., 2013), and mouse 3T3-L1 adipocytes (Moore et al., 2005). Methods used by us and others (Crunk et al., 2013) allowed not only to localize LDs within cell compartments, but also determine LD percentage of cell volume, total and individual LD volume, number and/or size (e.g., mean and median individual LD volume/cell).

Lipid droplets in the CL or cultured luteal cells have been identified by using electron microscopy for several species including humans, rats, rabbits, cows and sheep (Blanchette, 1966; Enders, 1973; Schmidt et al., 1984; O'Shea et al., 1986, 1989; Yuh et al., 1986; Fields et al., 1992; Fields and Fields, 1996; Towns et al., 1999). In our study, we not only identified presence and localization of LDs in LLC and SLC but we also quantified LDs demonstrating that the mean and median volume of individual LD was greater in SLC than LLC. In fact, LLC and SLC have been well characterized in numerous studies demonstrating differences in size (e.g., diameter or volume), morphology, responsiveness to $\mathrm{LH}$ and prostaglandin $\mathrm{F}_{2 \alpha}$, (PGF) steroidogenic activity, expression of numerous antigens and other features (Niswender and Nett, 1994; O'Shea et al., 1986, 1989; Stouffer et al., 2007; Stouffer and Hennebold, 2015). Thus, it is not surprising that in addition to these differences, LLC and SLC also differ in LDs dynamics.

The present data demonstrated that LD total and individual volume and number were affected by cell type (e.g., LLC vs. SLC), and stage of the estrous cycle. In addition, plane of nutrition tended to affect the percentage of cell volume occupied by LD. However, cell volume occupied by LDs was similar in LLC and SLC. Since LLC are much larger than SLC, it was 
expected that individual LD volume would also be greater in LLC. However, individual LD volume and the number/cell were less in LLC than SLC indicating differences in LD formation process and/or function. We hypothesize that detected differences in LD expression between SLC and LLC are associated with different cell responsiveness to regulatory factors (such as LH, PGF or others) and/or different steroidogenic activity/P4 secretion. However, to fully explain cause(s) of these differences, additional studies should be undertaken.

Several measurements of LDs including LD volume, number/cell and cell volume occupied by LDs were greater at the mid than early luteal stage of the estrous cycle. Since CL weight and P4 secretion increases from the early to mid-luteal phase, observed changes in LD measurements are likely associated with luteal cell differentiation and growth during the estrous cycle (Jablonka-Shariff et al., 1993; Stouffer and Hennebold, 2015).

In this study, we observed interactions among plane of nutrition, stage of the estrous cycle and cell type, indicating diet effects on selected measurements of LDs in ovine LLC and SLC. In cows, diets containing calcium soaps of fatty acids enhanced the percentage of area of SLC, LLC and total area occupied by lipids in the CL from the mid-luteal phase (Hawkins et al., 1995). This increase was associated with increased serum concentration of cholesterol, highdensity lipoprotein (HDL) and P4 (Hawkins et al., 1995). In our experiment, plane of nutrition did not affect serum P4 at the time of tissue collection. On the other hand, we have demonstrated greater serum P4 concentration during the estrous cycle in ewes fed excess diet (Kaminski et al., 2015). However, increased LD volume in LLC in O ewes, and LD volume expressed as a percentage of cell volume in LLC in O, and SLC in U, at the mid-luteal stage in the present experiment indicates functional changes caused by plane of nutrition. Thus, these data suggest that LD dynamics may be affected by diet composition and level of energy in diet. The 
importance of LD dynamics in luteal cells in animals fed different planes of nutrition, an association between total and individual LD volume and $\mathrm{P} 4$ secretion and/or other luteal functions should be investigated in the future.

Although the presence of LDs in luteal cells is very well documented for numerous species (as discussed above), their specific role in luteal functions has not been studied in detail. Several decades ago, it was hypothesized that the presence of LDs in luteal cells is associated with their secretory/steroidogenic activity (Blanchette, 1966; Enders, 1973). The steroidogenic system in the CL includes several enzymes such as $3 \beta$-hydroxysteroid dehydrogenese (HSD3B), P450 side chain cleavage (CYP11A1), steroidogenic acute regulatory protein (StAR), cholesteryl ester hydrolase (or HSL), and precursors for steroids such as cholesterol or cholesterol esters (e.g., low or high density lipoproteins) (Aten et al., 1995; Lobo et al., 2009; Stouffer et al., 2007). Furthermore, differential expression of HSL (an intracellular neutral lipase that hydrolyzes triacylglycerols, diacylglycerols, and monoacylglycerols, as well as cholesterol) in the rat reproductive system including the CL during the estrous cycle indicates that LDs may be involved in the cholesterol ester hydrolysis for the synthesis of steroid hormones (Lobo et al., 2009). In fact, it has been demonstrated that in the CL, steroidogenesis depends on exogenous cholesterol, supplied by lipoproteins and mobilized from LDs by HSL or neutral cholesteryl ester hydrolase (Strauss et al., 1981; Gwynne and Straus, 1982). In our study, P4 concentration in medium and several measurements of LDs including LD volume, number and proportion of cell occupied by LD were greater at the mid than early luteal phase indicating a possible association between P4 secretion and LD function. Thus, these data seem to support previous observations suggesting that LDs are involved in steroidogenesis. However, future studies of LD composition using lipidomics and functional analyses should be undertaken to not only characterize luteal LD 
content, but also to better understand their importance for steroid production and other processes in the CL.

In summary, application of advanced imaging technology and image analytical techniques, although time-consuming, allowed for determination of individual LD measurements, such as number, mean volume, median size, and volume, as well as total LD and cell volumes, in LLC and SLC. Thus, these data conclusively show that LD dynamics differ among parenchymal steroidogenic luteal cell types. Furthermore, we present novel findings that LD dynamics in ovine luteal cells are affected by the stage of luteal development and nutritional plane, which has not been studied in detail. Regulation of LD function, and especially in association with P4 secretion and proteins controlling lipid metabolism, warrants further study, since altered LD function may lead to luteal dysfunction that in turn contributes to infertility in mammalian species.

\section{Acknowledgements}

This project was supported by the USDA-AFRI grant 2011-67016-30174 and Hatch Projects ND01754 and ND01748 to ATGB and DAR. Vilaivan Khanthusaeng and Jiratti Thammasiri, Ph.D. candidates supported by grant from The Thailand Research Fund (TRF) under Research and Researchers for Industries (RRI), Research Fund for Supporting Lecturer to Admit High Potential Student to Study and Research on His Expert Program Year 2013, Graduate School, Khon Kaen University and National Research Council of Thailand (NRCT). The authors would like to thank Dr. Joel Caton for consultations concerning animal diets, Dr. Sheri Dorsam for laboratory assistance, and Jim Kirsch, Terry Skunberg, the staff at NDSU Animal Nutrition and Physiology Center for assistance in animal care. 


\section{References}

Aten RF, Kolodecik TR, Macdonald GJ, Behrman HR. Modulation of cholesteryl ester hydrolase messenger ribonucleic acid levels, protein levels, and activity in the rat corpus luteum. Biol Reprod 1995;53:1110-7.

Beller M, Thiel K, Thul PJ, Jäckle H. Lipid droplets: a dynamic organelle moves into focus. FEBS Lett 2010;584:2176-82.

Blanchette EJ. Ovarian steroid cells. II. The lutein cell. J Cell Biol 1966;31:517-42.

Brasaemle DL, Wolins NE. Packaging of fat: an evolving model of lipid droplet assembly and expansion. J Biol Chem 2012;287:2273-9.

Crunk AE, Monks J, Murakami A, Jackman M, Maclean PS, Ladinsky M, et al. Dynamic regulation of hepatic lipid droplet properties by diet. PLoS One 2013;8:e67631.

Devoto L, Kohen P, Muñoz A, Strauss JF 3rd. Human corpus luteum physiology and the lutealphase dysfunction associated with ovarian stimulation. Reprod Biomed Online 2009;18 (Suppl 2):19-24.

Digel M, Ehehalt R, Füllekrug J. Lipid droplets lighting up: insights from live microscopy. FEBS Lett 2010;584:2168-75.

Enders AC. Cytology of the corpus luteum. Biol Reprod 1973;8:158-82

Farese RV Jr, Walther TC. Lipid droplets finally get a little R-E-S-P-E-C-T. Cell. 2009;139: 855-60.

Fields MJ, Fields PA. Morphological characteristics of the bovine corpus luteum during the estrous cycle and pregnancy. Theriogenology 1996;45:1295-325.

Fields MJ, Barros CM, Watkins WB, Fields PA. Characterization of large luteal cells and their secretory granules during the estrous cycle of the cow. Biol Reprod 1992;46:535-45. 
Fujimoto T, Ohsaki Y, Suzuki M, Cheng J. Imaging lipid droplets by electron microscopy. Methods Cell Biol 2013;116:227-51.

Grazul-Bilska AT, Bass CS, Kaminski SL, Perry G, Redmer DA. Secretion of progesterone by ovine granulosa cells: effects of nitric oxide and plane of nutrition. Can J Physiol Pharmacol 2015;8:1-6.

Grazul-Bilska AT, Borowczyk E, Bilski JJ, Reynolds LP, Redmer DA, Caton JS, et al. Overfeeding and underfeeding have detrimental effects on oocyte quality measured by in vitro fertilization and early embryonic development in sheep. Domest Anim Endocrinol 2012;43:289-298,.

Grazul-Bilska AT, TL Neville, E Borowczyk, A Sharma, LP Reynolds, JS Caton, DA Redmer, and KA Vonnahme. Ovarian and uterine characteristics and onset of puberty in adolescent offspring: Effects of maternal diet and Se supplementation in sheep. Theriogenology 2014;81:887-95.

Grazul-Bilska AT, Redmer DA, Reynolds LP. Secretion of angiogenic activity and progesterone by ovine luteal cell types in vitro. J Anim Sci 1991;69:2099-107.

Grazul-Bilska AT, Reynolds LP, Bilski JJ, Redmer DA. Effects of second messengers on gap junctional intercellular communication of ovine luteal cells throughout the estrous cycle. Biol Reprod 2001;65:777-83.

Greenberg AS, Coleman RA. Expanding roles for lipid droplets. Trends Endocrinol Metab 2011;22:195-6.

Greenberg AS, Coleman RA, Kraemer FB, McManaman JL, Obin MS, Puri V, et al. The role of lipid droplets in metabolic disease in rodents and humans. J Clin Invest 2011;121:2102-10. 
Gwynne JT, Strauss JF 3rd. The role of lipoproteins in steroidogenesis and cholesterol metabolism in steroidogenic glands. Endocr Rev 1982;3:299-329.

Hawkins DE, Niswender KD, Oss GM, Moeller CL, Odde KG, Sawyer HR, et al. An increase in serum lipids increases luteal lipid content and alters the disappearance rate of progesterone in cows. J Anim Sci 1995;73:541-5.

Jablonka-Shariff A, Grazul-Bilska AT, Redmer DA Reynolds LP. Growth and cellular proliferation of ovine corpora lutea throughout the estrous cycle. Endocrinology $1993 ; 133: 1871-97$

Kaminski SL, Redmer DA, Bass CS, Keisler DH, Carlson LS, Vonnahme KA, et al. The effects of diet and arginine treatment on serum metabolites and selected hormones during the estrous cycle in sheep. Theriogenology 2015;83:808-16.

Konige M1, Wang H1, Sztalryd C2. Role of adipose specific lipid droplet proteins in maintaining whole body energy homeostasis. Biochim Biophys Acta 2014;1842:393-401.

Klymchenko AS, Kreder R. Fluorescent probes for lipid rafts: from model membranes to living cells. Chem Biol 2014;21:97-113.

Lobo MV1, Huerta L, Arenas MI, Busto R, Lasunción MA, Martín-Hidalgo A. Hormonesensitive lipase expression and IHC localization in the rat ovary, oviduct, and uterus. $\mathbf{J}$ Histochem Cytochem 2009;57:51-60.

Londos C, Brasaemle DL, Gruia-Gray J, Servetnick DA, Schultz CJ, Levin DM, et al. Perilipin: unique proteins associated with intracellular neutral lipid droplets in adipocytes and steroidogenic cells. Biochem Soc Trans 1995;23:611-5.

Majzner K, Kochan K, Kachamakova-Trojanowska N, Maslak E, Chlopicki S, Baranska M. 
Raman imaging providing insights into chemical composition of lipid droplets of different size and origin: in hepatocytes and endothelium. Anal Chem 2014;86:6666-74.

Manna PR, Stetson CL, Slominski AT, Pruitt K. Role of the steroidogenic acute regulatory protein in health and disease. Endocrine 2015 [Epub ahead of print].

Melo RC, Paganoti GF, Dvorak AM, Weller PF. The internal architecture of leukocyte lipid body organelles captured by three-dimensional electron microscopy tomography. PLoS One 2013;8:59578.

Milvae RA, Hinckley ST, Carlson JC. Luteotropic and luteolytic mechanisms in the bovine corpus luteum. Theriogenology 1996;45:1327-49.

Miyamoto A, Shirasuna K, Sasahara K. Local regulation of corpus luteum development and regression in the cow: Impact of angiogenic and vasoactive factors. Domest Anim Endocrinol 2009;37:159-69.

Moore HP, Silver RB, Mottillo EP, Bernlohr DA, Granneman JG. Perilipin targets a novel pool of lipid droplets for lipolytic attack by hormone-sensitive lipase. J Biol Chem 2005;280:43109-20.

Murphy S, Martin S, Parton RG. Lipid droplet-organelle interactions; sharing the fats. Biochim Biophys Acta 2009;1791:441-7.

Niswender GD. Molecular control of luteal secretion of progesterone. Reproduction 2002;123:333-9.

Niswender GD, Juengel JL, McGuire WJ, Belfiore CJ, Wiltbank MC. Luteal function: the estrous cycle and early pregnancy. Biol Reprod 1994;50:239-47. 
Niswender GD, TM Nett. Corpus luteaum and its control in infraprimate species. In: Knobil E and Neil JD , editors. The Physiology of Reproduction, $2^{\text {nd }}$ ed.; Raven Press, New York, 1994. p. 781-815.

O’Callaghan, D, Boland MP. Nutritional effects on ovulation, embryo development and the establishment of pregnancy in ruminants. Anim Sci 1999;68:299-314.

O'Shea JD, Rodgers RJ, D'Occhio MJ. Cellular composition of the cyclic corpus luteum of the cow. J Reprod Fertil 1989;85:483-7.

O'Shea JD, Rodgers RJ, McCoy K, D'Occhio MJ. Ultrastructural cytology of the cyclic corpus luteum of the cow. Acta Anat (Basel) 1990;138:154-65.

O'Shea JD, Rodgers RJ, Wright PJ. Cellular composition of the sheep corpus luteum in the midand late luteal phases of the oestrous cycle. J Reprod Fertil 1986;76:685-91.

Ohsaki Y, Suzuki M1, Fujimoto T. Open questions in lipid droplet biology. Chem Biol 2014;21:86-96.

Ohsaki Y, Shinohara Y, Suzuki M, Fujimoto T. A pitfall in using BODIPY dyes to label lipid droplets for fluorescence microscopy. Histochem Cell Biol 2010;133:477-80.

Prats C, Gomez-Cabello A, Nordby P, Andersen JL, Helge JW, Dela F, et al. An optimized histochemical method to assess skeletal muscle glycogen and lipid stores reveals two metabolically distinct populations of type I muscle fibers. PLoS One 2013;8:77774.

Previs SF, McLaren DG, Wang SP, Stout SJ, Zhou H, Herath K, et al. New methodologies for studying lipid synthesis and turnover: looking backwards to enable moving forwards. Biochim Biophys Acta 2014;1842:402-13.

Shirasuna K, Nitta A, Sineenard J, Shimizu T, Bollwein H, Miyamoto A. Vascular and immune 
regulation of corpus luteum development, maintenance, and regression in the cow. Domest Anim Endocrinol 2012;43:198-211.

Schmidt CL, Kendall JZ, Dandekar PV, Quigley MM, Schmidt KL. Characterization of longterm monolayer cultures of human granulosa cells from follicles of different size and exposed in vivo to clomiphene citrate and hCG. J Reprod Fertil 1984;71:279-87.

Spangenburg EE, Pratt SJ, Wohlers LM, Lovering RM. Use of BODIPY (493/503) to visualize intramuscular lipid droplets in skeletal muscle. J Biomed Biotechnol 2011;2011:598358.

Stouffer RL, Bishop CV, Bogan RL, Xu F, Hennebold JD. Endocrine and local control of the primate corpus luteum. Reprod Biol 2013;13:259-71.

Stouffer RL, Hennebold JD. Structure, function and regulation of the corpus luteum. In: Plant TM and Zelznik AJ, editors. The Knobil and Neill's Physiology of Reproduction, 4nd ed. Eds; Academic Press as an imprint of Elsevier, New York , 2015. P. 1023-76.

Stouffer RL, Xu F, Duffy DM. Molecular control of ovulation and luteinization in the primate follicle. Front Biosci. 2007 Jan 1;12:297-307.

Straub BK, Gyoengyoesi B, Koenig M, Hashani M, Pawella LM, Herpel E, et al. Adipophilin/perilipin-2 as a lipid droplet-specific marker for metabolically active cells and diseases associated with metabolic dysregulation. Histopathology 2013;62:617-31.

Straub BK, Stoeffel P, Heid H, Zimbelmann R, Schirmacher P. Differential pattern of lipid droplet-associated proteins and de novo perilipin expression in hepatocyte steatogenesis. Hepatology 2008;47:1936-46.

Strauss JF 3rd, Schuler LA, Rosenblum MF, Tanaka T.Cholesterol metabolism by ovarian tissue. Adv Lipid Res 1981;18:99-157.

Suzuki M, Shinohara Y, Fujimoto T. Histochemical detection of lipid droplets in cultured cells. 
Methods Mol Biol 2013;931:483-91.

Towns R1, Menon KM, Brabec RK, Silverstein AM, Cohen JM, Bowen JM, et al.

Glucocorticoids stimulate the accumulation of lipids in the rat corpus luteum. Biol Reprod 1999;61:416-21.

Vonnahme KA, Redmer DA, Borowczyk E, Bilski JJ, Johnson ML, Reynolds LP, et al. Vascular composition, apoptosis, and expression of angiogenic factors in the corpus luteum during prostaglandin F2 $\alpha$ - induced regression in sheep. Reproduction 2006;131:1115-1126.

Walther TC, Farese RV Jr. Lipid droplets and cellular lipid metabolism. Annu Rev Biochem 2012;81:687-714.

Wilfling F, Haas JT, Walther TC, Farese RV Jr. Lipid droplet biogenesis. Curr Opin Cell Biol 2014;29:39-45.

Zechner R1, Zimmermann R, Eichmann TO, Kohlwein SD, Haemmerle G, Lass A, Madeo F. FAT SIGNALS--lipases and lipolysis in lipid metabolism and signaling. Cell Metab 2012;15:279-91.

Yang H1, Galea A, Sytnyk V, Crossley M.Controlling the size of lipid droplets: lipid and protein factors. Curr Opin Cell Biol 2012;24:509-16.

Yuh KC, Possley RM, Brabec RK, Keyes PL. Steroidogenic and morphological characteristics of granulosa and thecal compartments of the differentiating rabbit corpus luteum in culture. $\mathrm{J}$ Reprod Fertil 1986;76:267-77. 
Fig. 1. Representative images of LDs staining in LLC (left column; A, C, E, G, and I) and SLC (right column; B, D, F, H, and J). A and B: representative confocal images of LLC and SLC; C and D: composite 3D rendered images showing lipid droplets, nuclei, and cell surface/volume; $\mathrm{E}$ and F: representative side view of surface of 3D rendered images; $\mathrm{G}$ and $\mathrm{H}$ : representative view of 3D rendered images of LDs and nucleus; I and J: representative side-view of 3D rendered images of LDs and nuclei. Green (in A and B) and brownish/reddish (in C, D, G, H, I and J) colors indicate LDs stained using BODIPY, and blue color indicates nuclei stained with DAPI. Note that scale bar for LLC (A, C, E, G and I) is $10 \mu \mathrm{m}$, and for SLC (B, D, F, H and J) is $5 \mu \mathrm{m}$. Note on A and C, presence of one SLC next to LLC that was not rendered/analyzed. Note smaller size of LD in LLC than SLC.

Fig. 2. Measurements of LLC and SLC from the early and mid-luteal phases of the estrous cycle in control (C), overfed (O) and underfed (U) sheep; A) cell volume; B) total LD volume/cell; C) LD number/cell; D) individual LD mean volume; E) individual LD median volume; and F) percentage of cell volume occupied by LDs. ${ }^{\mathrm{a}, \mathrm{b}, \mathrm{c}} \mathrm{P}<0.01-0.09$; values with different superscripts differ within each graph. 
Large luteal cell
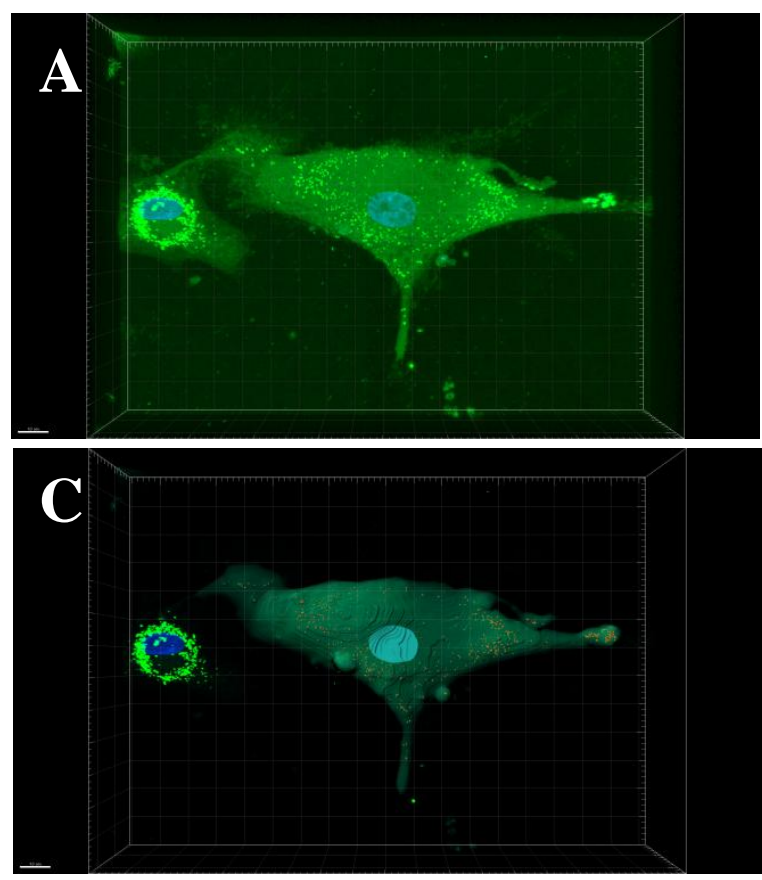

E

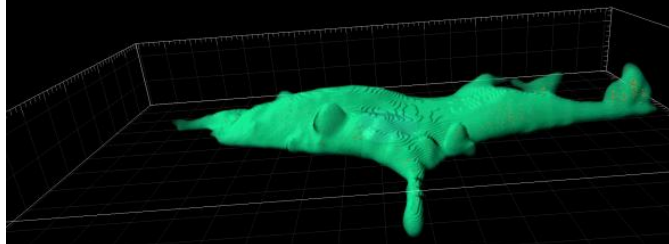

-

G

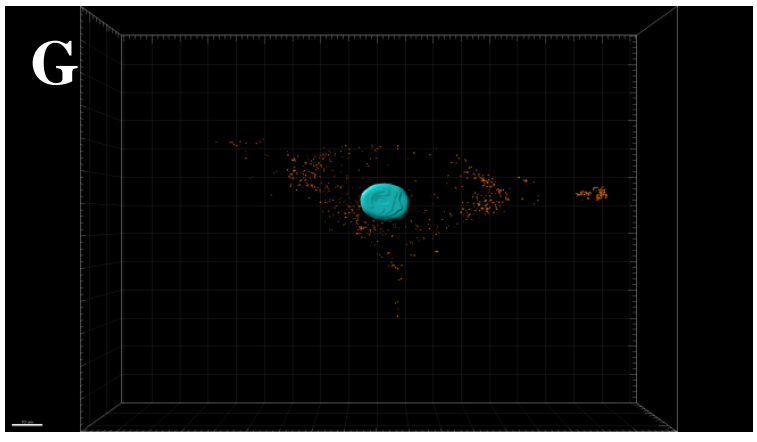

I

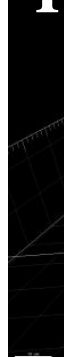

Small luteal cell

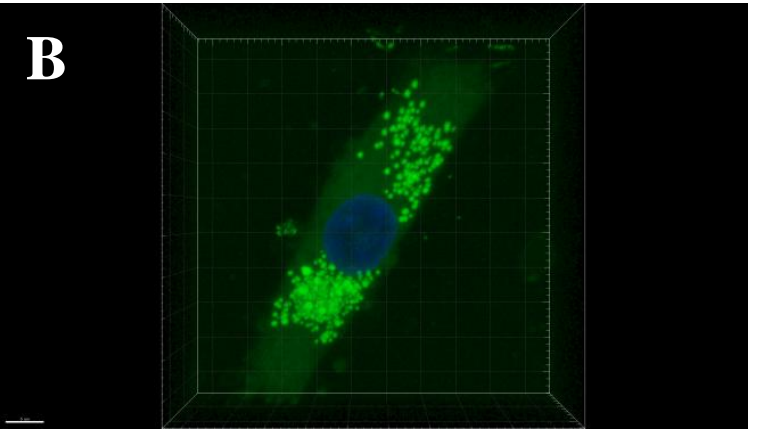

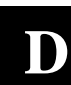

F

H

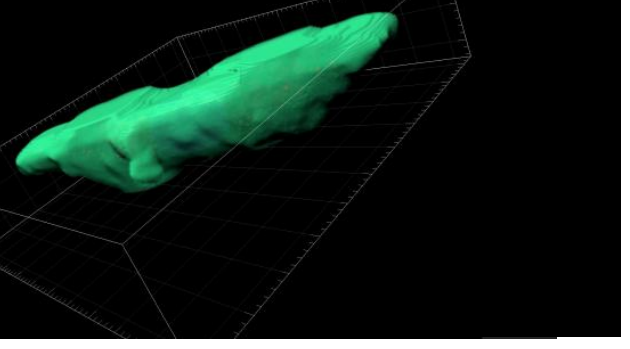

J 


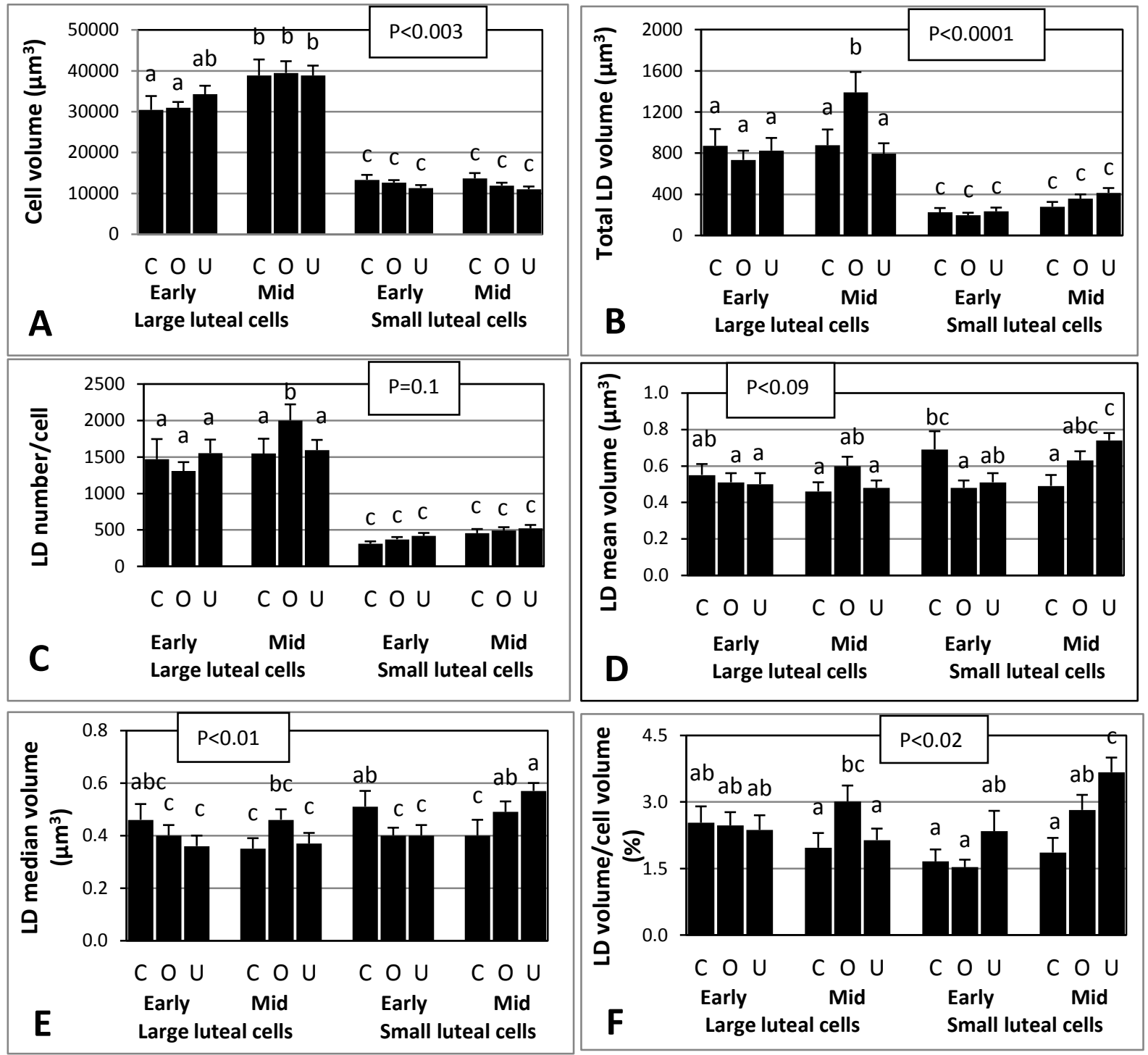


Table 1: Composition of the diet ${ }^{1}$

\begin{tabular}{lcccc}
\hline Amount as fed in mix & Diet DM \% & \% DM & Amount As Fed (lbs) & Diet \% As Fed \\
\hline Beet Pulp & 36.5 & 91 & 40.1 & 36.2 \\
Alfalfa Meal & 22.3 & 90 & 24.8 & 22.3 \\
Corn & 18.2 & 88 & 20.7 & 18.7 \\
Soy Hulls & 20.0 & 91 & 22.0 & 19.8 \\
Soy Bean Meal & 3.0 & 90 & 3.3 & 3.0 \\
\hline
\end{tabular}

${ }^{\mathrm{I}}$ To provide $2.4 \mathrm{Mcal}$ of metabolizable energy (ME)/kg of diet and contain $14 \%$ crude protein (dry matter basis) 